\title{
Morphometry of Deutero Malay female nose
}

\author{
Theddeus O.H Prasetyono, Karina F. Moegni \\ Division of Plastic Surgery, Department of Surgery, Faculty of Medicine University of Indonesia/ Cipto Mangunkusumo Hospital, \\ Jakarta, Indonesia
}

\begin{abstract}
Abstrak
Tujuan Tujuan studi ini adalah melakukan pengukuran morfometrik hidung untuk memperoleh ukuran-ukuran normal yang dapat merepresentasikan bangsa Asia, khususnya subras Deutero Melayu.

Metode Studi potong lintang dilakukan terhadap 126 subjek mahasiswi Fakultas Kedokteran Universitas Indonesia, Jakarta. Subjek dibatasi hanya yang berasal dari subras Deutero Melayu (termasuk di dalamnya meliputi suku Aceh, Jawa, Sunda, Minangkabau, Riau, dan Bugis) dalam 3 generasi ke atas. Subjek difoto dengan menggunakan kamera digital untuk memperoleh gambar penampakan frontal, profil kiri, dan basal. Selanjutnya gambar disimpan secara elektronik dalam format JPEG dan digunakan untuk memperoleh ukuran-ukuran linear dan angular.

Hasil Lebar interkantalis 3,56 cm 0,27, lebar alar 4,14 $\mathrm{cm} \pm 0,28$, panjang hidung 4,0 $\mathrm{cm} \pm 0,21$, proyeksi pronasi $2,29 \mathrm{~cm} \pm 0,26$, sudut puncak hidung (nasal tip) 111,5o \pm 4.4, sudut nasofrontal 134,6o \pm 7,3, sudut nasofasial 36,3o \pm 4,3, sudut nasolabial 90,4o \pm 83, dan proyeksi nasi 0,43 $\mathrm{cm} \pm 0,22$.

Kesimpulan Data yang didapat dari studi ini dapat digunakan sebagai ukuran normal dalam kasus hidung perempuan Deutero Melayu dan dapat digunakan sebagai acuan dalam perencanaan operasi serta hasil operasi rinoplasti estetik atau rekonstruksi pasien Deutero Melayu. (Med J Indones 2009; 18: 189-92)
\end{abstract}

\begin{abstract}
Aim The objective of this study is to carry out morphometric measurements of the nose, in order to establish norms for the Indonesian as the representation of Asian, specifically for the Deutero Malay sub race.

Method A cross sectional study was performed on 126 subjects, recruited from female students of Medical Faculty, the University of Indonesia, Jakarta. Subjects were restricted within Deutero Malay sub race (including ethnic groups of Aceh, Jawa, Sunda, Minangkabau, Riau and Bugis) in 3 generations. Subjects were photographed with digital camera in frontal, left lateral and basal view. Then from the photographs which were stored as JPEG files, linear as well as angular measurements were carried out.

Results The intercanthal width is $3.56 \mathrm{~cm} \pm 0.27$, alar width $4.14 \mathrm{~cm} \pm 0.28$, length of the nose $4.0 \mathrm{~cm} \pm 0.21$, pronasion projection $2.29 \mathrm{~cm} \pm 0.26$ and tip angle $111.50 \pm 4.4$, nasofrontal angle $134.60 \pm 7.3$, nasofacial angle 36.30 \pm 4.3, nasolabial angle $90.40 \pm 8.3$, and nasion projection $0.43 \mathrm{~cm} \pm 0.22$.

Conclusions The data collected from this study can be used as norms for Deutero Malay cases and will serve as a guide for quick reference, when planning aesthetic or reconstructive rhinoplasties for the Deutero Malay patient. (Med J Indones 2009; 18: 189-92)
\end{abstract}

Key words: Deutero Malay, digital photograph, nose, morphometry

Beauty is an ill-defined concept, which can be described as something which gives the highest degree of pleasure to the senses or to the mind and suggests that the object of delight approximates one's conception of an ideal (Webster, 1988). ${ }^{1}$ Standards of beauty change overtime and across cultures; ${ }^{2}$ but still in non Caucasian countries, the golden standard of beauty is somewhat aiming at Caucasian normative standard and what was considered as the original race beauty is often becoming less popular.

Cosmetic plastic surgery is one of the choices of achieving beauty. This operative procedure has regain popularity, and one of the top five procedures across United States is rhinoplasty. American Society of Plastic Surgeons stated that more than 307.000 people in United States went through cosmetic rhinoplasty in 2006. ${ }^{3}$ In Cipto Mangunkusumo Hospital, Jakarta, Indonesia as the top referral hospital in the country, rhinoplasty covers around $40 \%$ of all cosmetic procedures that were done in Plastic Surgery ODC (one day care) operating theatre during the year of 2005-2006.

As the patient population remains racially diverse, plastic surgeons are often faced with the challenge 
of achieving patient satisfaction after rhinoplasty for different racial groups. Indonesian nose, which has been broadly classified as mesorrhine like other Asian nose, ${ }^{4}$ has unique anatomy and morphology. Due to the lack of datas on Indonesian nose, this study is aimed to carry out morphometric measurements of the nose, in order to establish norms for the Indonesian as the representation of Asian, specifically for the Deutero Malay race.

\section{METHODS}

Ethical approval was obtained from the Committee on Medical Research Ethics, University of Indonesia, Jakarta. Subjects were recruited from students of Medical Faculty, University of Indonesia, Jakarta, restricted to females within Deutero Malay sub race (including ethnic groups of Aceh, Jawa, Sunda, Minangkabau, Riau and Bugis) ${ }^{5}$ inherited in 3 generations without interference from any other sub race(s). Those outside the age group of 18-25 were excluded, as were subjects with history of previous nasal trauma, corrective nasal surgery, congenital anomaly and present disease that could affect morphometry of the nose.

Subjects were photographed with SLR Canon EOS 350D digital camera placed 1 meter in front of the subject. The camera was set in 8 megapixels resolution and a $105 \mathrm{~mm}$ focal lens was selected to maintain the natural proportion, with studio setting using 1 main flash, additional reflector \& soft box 450 in front of the subject. ${ }^{6}$ The subject sat down with relax facial expression 75 $\mathrm{cm}$ in front of blue back-screen and three views were taken: frontal, left lateral and basal. Standardization was achieved by using a centimeter-ruler held against the plane of the face. To avoid the bias, after each subject was photographed, the frontal view photograph was enlarged on computer to life-size, and then the real alar width measurement was compared to one in the photo. All of the photographs were stored as JPEG files.

The following measurements were made (Figs 1-3):

(1) intercanthal width,

(2) alar width,

(3) nasofrontal angle,

(4) length of the nose (nasion to pronasion),

(5) nasofacial angle,

(6) nasion projection,

(7) pronasion projection, as an indicator of tip projection,

(8) tip angle,

(9) nasolabial angle, and

(10) base of the nose width.

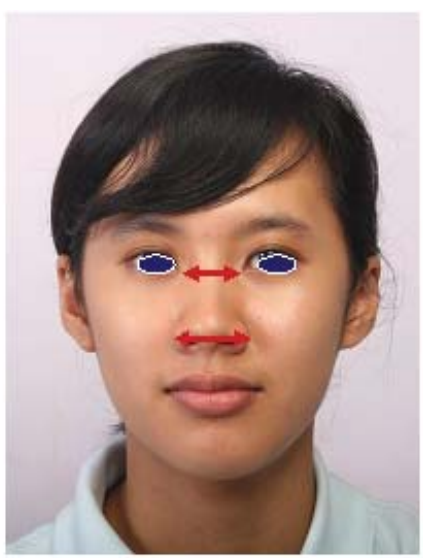

Figure 1. Frontal view: measurements of interchantal and alar widht
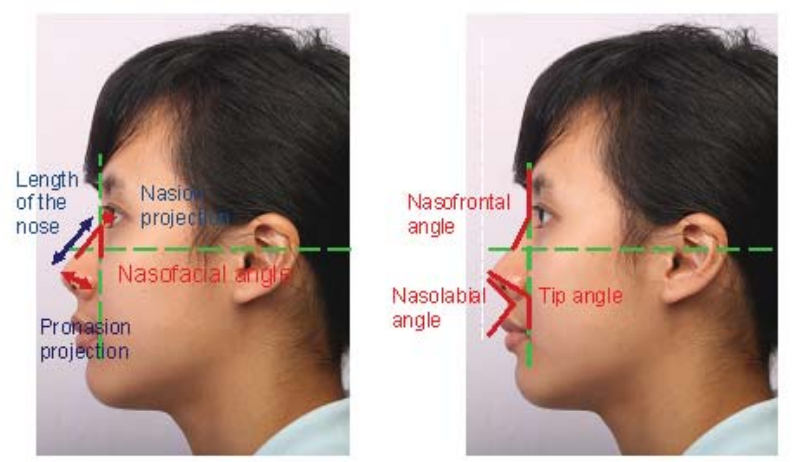

Figure 2. Left lateral view

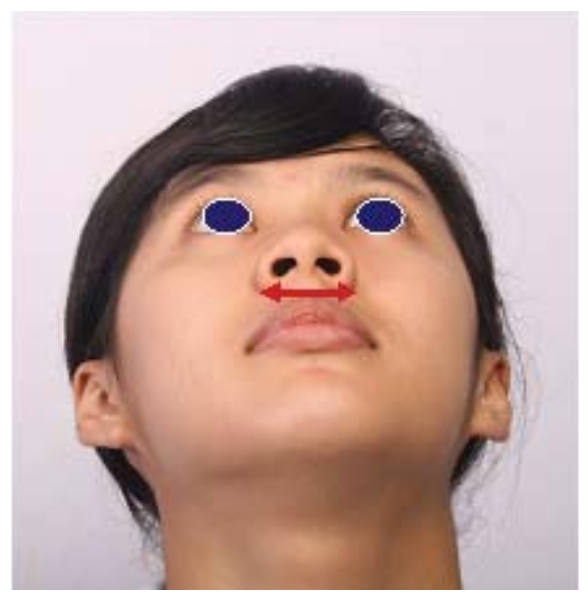

Figure 3. Basal view : measurement of base of the nose widht

\section{RESULTS}

One hundred and thirty one women were recruited into this study, but 5 were excluded because their ages were beyond 25 year-old. The distribution of ethnic groups is described in Table 1. 
Tabel 1. Distribution of ethnic groups

\begin{tabular}{clcc}
\hline No. & Ethnic group & $\mathrm{N}$ & $\%$ \\
\hline 1. & Minangkabau & 21 & 16.7 \\
2. & Jawa & 60 & 47.6 \\
3. & Aceh & 2 & 1.6 \\
4. & Sunda & 6 & 4.7 \\
5. & Riau & 2 & 1.6 \\
6. & Bugis & 2 & 1.6 \\
7. & Mixed & 33 & 26.2 \\
\hline & TOTAL & 126 & 100 \\
\hline
\end{tabular}

Table 2. Nose measurements

\begin{tabular}{clcccc}
\hline No. & \multicolumn{1}{c}{ Parameter } & Min & Max & Mean & SD \\
\hline 1. & Intercanthal width $(\mathrm{cm})$ & 3 & 4.1 & 3.56 & 0.27 \\
2. & Alar width $(\mathrm{cm})$ & 3.6 & 4.8 & 4.14 & 0.28 \\
3. & Nasofrontal angle $\left(^{\circ}\right)$ & 119 & 150 & 134.6 & 7.3 \\
4. & Length of the nose $(\mathrm{cm})$ & 3.6 & 4.3 & 4 & 0.21 \\
5. & Nasofacial angle $\left(^{\circ}\right)$ & 30 & 47 & 36.3 & 4.3 \\
6. & Nasion projection $(\mathrm{cm})$ & 0.1 & 0.8 & 0.43 & 0.22 \\
7. & Pronasion projection $(\mathrm{cm})$ & 1.5 & 3 & 2.29 & 0.26 \\
8. & Tip angle $\left({ }^{\circ}\right)$ & 104 & 121 & 111.5 & 4.4 \\
9. & Nasolabial angle $\left(^{\circ}\right)$ & 81 & 110 & 90.4 & 8.3 \\
10. & Base of the nose width $(\mathrm{cm})$ & 3.2 & 4.2 & 3.69 & 0.29 \\
\hline
\end{tabular}

\section{DISCUSSION}

Nose is the most prominent aesthetic unit on the face, and just like any other prominent structures, it has 3 components: external tissue, framework, and supporting tissues. The nasal skin is less elastic due to the excessive amount of sebaceous glands and subcutaneous fat. When people gets older, the nasal skin will become thinner and cartilage framework can be seen, also the tip of the nose will drop. ${ }^{7,8}$

Race is by means a population of people who share the same acquired physical appearance. There are 2 main sub races in Indonesia, which are called Proto Malay and Deutero Malay. Proto Malay is believed as the first Malay race that entered Indonesia through the Asiatic peninsula, following a migration wave at about 25001500 BC. Many studies had traced back that the home of the Malay race to the Northwestern part of Yunnan, in China. On second migration at about 300 BC came Deutero Malay, which then spread to become the people of Aceh, Jawa, Sunda, Minangkabau, Riau, Bugis, and some parts of Tamiang, Melayu Deli, Jambi, Bengkulu, Palembang, Makassar, Bali, Sasak. ${ }^{9-11,15}$

Although the Deutero Malay people spread out to different parts of the Indonesian archipelago and create many sub races, they all have the same great ancestors from which their features were inherited. Environmental forces of these different areas have less, almost none, effect on the original facial feature of a Deutero Malay race. Had there been any slight differences in the nose features between the sub races, they are accounted as insignificant. Just like European Caucasians and Japanese races are looked at as a whole regardless the different sub races from different places and environments in Europe and Japan, Deutero Malay race should be looked up as a whole, rather than pieces of different sub races and environmental factors. Thus, the number of samples from different sub races should not be affecting the outcome of the results of physical performance. ${ }^{13,14}$

Racial factor plays an important role in morphometry of the nose. Oriental nose usually has low and wide bridge which is undefined clearly to finish at a round tip. Nasal dorsum is described as a soft curve, compares to the sharp look of Caucasian nose. Tip protrusion in Oriental is less prominent and the alar is wider. ${ }^{12}$

Leong and White (2004) has studied the differences between Oriental and Caucasian nose from 118 healthy people in England from the photograph with frontal, lateral, and basal views. ${ }^{13}$ Mishima et al (2000) did research on 129 Japanese from facial plaster models. ${ }^{14}$ Aung, Foo dan Lee (2000) in Singapore used a laser surface scanner to obtain anthropometric measurements of 90 Oriental subjects and noted that the Oriental nose was on average broader and exhibited less tip projection compared with the described Caucasian ideal. ${ }^{12}$

This study revealed that Deutero Malay women's nose measurements are at some points similar to those of Oriental/Chinese, including intercanthal width, alar width, length of the nose, pronasion projection, and tip angle. On the other hand, the nasofrontal angle, nasofacial angle, and nasolabial angle are wider whereas the nasion projection is shorter. These results can be used either as a parameter for rhinoplasty on a Deutero Malay race, or even as a guideline for a beautiful nose on a Deutero Malay face. Also this study can be used as an armamentarium of a research on facial esthetics of the Deutero Malays. For example; when a 
western doctor intends to do a rhinoplasty on an Asian, he would have a guideline of the nose features of the Deutero Malays. This can be useful as many Deutero Malays live in the west coast of America.

Although the study subjects compromised of medical students, their socio-economical status does not affect their facial features, as we have excluded those with nose trauma or previous rhinoplasties. However, it is important that these results are not regarded as normal values from a random population sample. Rather these aesthetic parameters should be seen as useful reference material obtained from a group of subjects who reported no concern over their facial aesthetics. Pursuit of an improved reference range will require further studies, preferably involving a random sample of the normal population.

A simple method in obtaining morphometric data of Indonesian nose, specifically the Deutero Malay sub race, had been performed. These basic datas can be used as norms of Deutero Malay cases and will serve as a guide for quick reference, when planning aesthetic or reconstructive rhinoplasties for the Deutero Malay patient, as well as to serve as guidance for further research.

In conclusions, the data collected from this study can be used as norms for Deutero Malay cases and will serve as a guide for quick reference, when planning aesthetic or reconstructive rhinoplasties for the Deutero Malay patient.

\section{REFERENCES}

1. Patnaik VVG, Rajan KS, Bala S. Anatomy of 'A Beautiful Face \& Smile’. J Anat Soc India. 2003; 52(1): 74-80.

2. Romo T, Abraham MT. The ethnic nose. Fac Plast Surg. 2003; 19: 269-77.
3. American Society of Plastic Surgeons. 2000/2005/2006 National Plastic Surgery Statistics [Cited: 2007, June 30]. Available from: http//www.plasticsurgery.org/

4. Riveiro PF. Angular photogrammetric analysis of the soft tissue facial profile. Euro J Orthodontics. 2003; 25(4): 393-4.

5. Kennedy R. Contours of culture in Indonesia. [Cited 2007, April 27]. Available from: http//www.jstor.org/

6. Galdino G, DaSilva D, Gunter JP. Digital photography for rhinoplasty. Plast Reconstr Surg. 2002; 109(4): 1421-34.

7. Janis JE, Rohrich RJ. Rhinoplasty. In: Thorne CH, Beasley RW, Aston SJ, Bartlett SP, Gurtner GC, Spear SL, (editors). Grabb and Smith's plastic surgery. 6th ed. Philadelphia: Lippincott Williams and Wilkins; 2007: 517-8.

8. Jewett BS. Anatomic considerations. In: Baker SR, Naficy S (editors). Principles of nasal reconstruction. St.Louise: Mosby; 2002: 13-5.

9. Herdiyanto A. Diferensiasi sosial dan stratifikasi sosial. 2nd ed. Jakarta: PT Grafindo Media Pratama; 1997: 7-10.

10. Sofwanhady R. Comparison of cranial base angle and facial angle among subject with class I malocclusion of different populations. A physical anthropology study. Jakarta: Department of Anatomy, Faculty of Medicine University of Indonesia. 1990. Unpublished.

11. Sofwanhady R, Minamiwati. Chepalic indices of Papua, Flores, Java and China Population in Jakarta. Jakarta: Department of Anatomy, Faculty of Medicine University of Indonesia. 1998. Unpublished.

12. Aung SC, Foo CL, Lee ST. Three dimensional laser scan assessment of the Oriental nose with a new classification of Oriental nasal types. Br J Plast Surg. 2000; 53: 109-16.

13. Leong SCL, White PS. A comparison of aesthetic proportions between the Oriental and Caucasian nose. Clin Otolaryngol. 2004; 29: 672-6.

14. Mishima K, Mori Y, Yamada T, Sugahara T. Anthropometric analysis of the nose in the Japanese. Cells Tissues Organs. 2002; 170(2-3): 198-206.

15. Sabri Zain. A history of the Malay Peninsula; Golden Chersonese: the first Malay Kingdoms. [Cited 2000, November 11]. Available from: http://www.sabrizain.org/ malaya/malays.htm 